\title{
Brazilian Journal \\ of Chemical

\section{CRISPY BANANA OBTAINED BY THE COMBINATION OF A HIGH TEMPERATURE AND SHORT TIME DRYING STAGE AND A DRYING PROCESS}

\author{
K. Hofsetz ${ }^{1}$ and C. C. Lopes ${ }^{2}$ \\ Laboratory of Applied Technology, Dept. of Food Engineering, Faculty of Food Engineering, \\ State University of Campinas, Phone: +(55)(19) 3788-4089, Fax: 55-19-3788-4027, \\ P.O. Box 6121, 13083-862, Campinas - SP, Brazil. \\ E-mail: khofsetz@fea.unicamp.br \\ E-mail: celso@fea.unicamp.br
}

(Received: October 20, 2004 ; Accepted: February 23, 2005)

\begin{abstract}
The effect of the high temperature and short time (HTST) drying stage was combined with an air drying process to produce crispness in bananas. The fruit was dehydrated in an air drier for five minutes at $70^{\circ} \mathrm{C}$ and then immediately set at a HTST stage $\left(130,140,150^{\circ} \mathrm{C}\right.$ and $9,12,15$ minutes) and then at $70^{\circ} \mathrm{C}$ until water activity $\left(\mathrm{a}_{\mathrm{w}}\right)$ was around 0.300 . Crispness was evaluated as a function of water activity, using sensory and texture analyses. Drying kinetics was evaluated using the empirical Lewis model. Crispy banana was obtained at $140^{\circ} \mathrm{C}-12 \mathrm{~min}$ and $150^{\circ} \mathrm{C}-15 \mathrm{~min}$ in the HTST stage, with $\mathrm{a}_{\mathrm{w}}=0.345$ and $\mathrm{a}_{\mathrm{w}}=0.363$, respectively. Analysis of the $\mathrm{k}$ parameter (Lewis model) suggests that the initial moisture content of the samples effects this parameter, overcoming the HTST effect. Results showed a relationship between sensory crispness, instrumental texture and the HTST stage.
\end{abstract}

Keywords: Banana; Drying; Crispness; Texture; Food.

\section{INTRODUCTION}

There is general agreement in texture research that this characteristic is the sensory and functional manifestation of the structural, mechanical and surface properties of food. Texture is being looked at not so much as the absence of defects, but as a positive quality attribute, denoting excellence in food preparation and contributing to eating enjoyment. In contrast to other sensory food attributes there is no single and specific receptor for texture because of its multiparameter nature. Some textural parameters are felt when the food is first placed in the mouth. This is the case whit crispness (Szczesniak, 2002).

Due to their fragility, brittle food particles can rarely be shaped into specimens with a well-defined shape and controlled dimensions, as is the norm in engineering materials testing. Consequently, most of these particulates must be tested either in their original form or in bulk. The resulting forcedisplacement compression is invariably irregular and irreproducible. However, the apparently random jaggedness of the force-displacement curves is not noise that should be discarded or eliminated. On the contrary, it is a source of useful information that should be retained and analysed (Peleg, 2003).

According to Luyten et al. (2003), appreciation of food products depends to a large extent on their crispy-crunchy nature. An exact characterization of these sensory attributes is not yet available, but there is a general consensus that the sensory sensations "crispy" and "crunchy" are related to the fracture

*To whom correspondence should be addressed 
properties of the materials. The definition of the sensation of "crispness" was proposed (Vincent, 1998) to be the sudden drop in load experience when a crispy food item breaks between the teeth. Forcedeflection curves of some starch-based crispy foods were studied as weighted frequency curves of the magnitude of the load drop. As the force on a crispy food item increases, so does the deformation and the object then starts to break. The author found the degree to which fracture is heard during the first bite affects the sensation of crispness. Since crispness may be associated with a rapid drop in force, this is related to the rapid propagation of the fracture, which in turn has a large effect on the brittle characteristic. If the material is brittle, i.e., it requires little work to fracture, the fracture will occur quickly (Vincent, 1998; Saklar et al., 1999).

Evaluating the instrumental data by approaches such as fractal analysis and peak analysis, Roudaut et al. (2000) found useful correlations for sensory crispness of low- moisture cereal products. The authors observed that an increase in water content alters the texture of starch-based samples from crispy to crackly. Other studies verified that food becomes crispier and requires less force to break as water activity and moisture content of the products decrease. If the increase in hardness occurs as water activity increases, this can be explained by the fact that water acts as a plasticizer, thereby increasing the hardness of the material. This is due to the fact that the plasticized structure does not disintegrate easily, allowing the sample to remain intact and offering more resistance to deformation (Duizer and Campanella, 1998; De Belie et al., 2000).

Katz and Labuza (1981) discussed the importance of water activity $\left(\mathrm{a}_{\mathrm{w}}\right)$ in crispness of snack food products. They concluded that amorphous to crystalline changes in simple carbohydratecontaining food systems begin to occur at water activity values in the range of 0.350 to 0.500 . Consequently the food became unacceptable from a sensory standpoint due to the loss of crispness. Toledo (1991) stated that when water activity value is lower than 0.700 it prevents microbiological damage, but to prevent deteriorative chemical and biochemical reactions, it is necessary that the dryness be reduced to a water activity value lower than 0.300 (Roudaut et al., 1998, 2000).

The objective of this work was to find a condition for obtaining crispy banana by combining the HTST drying stage and a drying process. Crispness was analysed by sensory and instrumental measurements. The drying kinetics was studied by applying an empirical drying model (Lewis model).

\section{MATERIAL AND METHODS}

\section{Material Preparation}

All fresh bananas (Musa acuminata Colla var. Cavendish) were purchased at a local market and stored in an air-conditioned room at $20^{\circ} \mathrm{C}$ until ready for drying. Bananas were peeled and sliced into pieces $1 \mathrm{~cm}$ thick and then cut at four equal slices, and both ends of the fruit were removed. The fruit chosen for the experiment was $19^{\circ}$ Brix and $21^{\circ}$ Brix. Two of the total of seven bananas used were purchased at a different market.

\section{Drying Process}

The drying process was carried out on a vertical dryer tray with an upward air flux (air drying). The dryer has two columns with an individual resistance block that permits control of the air temperature by a PID controller. One of the columns reaches high temperatures $\left(150^{\circ} \mathrm{C}\right)$ and a $2 \mathrm{HP}$ centrifugal ventilator is connected to both. The columns have independent adjustable valves which allows air velocity control. One column has a capacity for three trays and the other for two. The columns have a 17 $\mathrm{cm}$ inside diameter and the trays have a $15 \mathrm{~cm}$ diameter. The air flows vertically over the trays and a U manometer monitors its velocity. The air velocity was set at $3 \mathrm{~m} \mathrm{~s}^{-1}$.

All drying experiments comprised a pretreatment of the fruit during five minutes at $70^{\circ} \mathrm{C}$, a dry HTST stage with three levels of temperature and three lengths of times $\left(130^{\circ} \mathrm{C}-9 \mathrm{~min}, 130^{\circ} \mathrm{C}-15 \mathrm{~min}, 150^{\circ} \mathrm{C}\right.$ $9 \mathrm{~min}, 150^{\circ} \mathrm{C}-15 \mathrm{~min}$ and three equal runs: $140^{\circ} \mathrm{C}$ $12 \min (\mathrm{a}), \quad 140^{\circ} \mathrm{C}-12 \mathrm{~min}(\mathrm{~b})$ and $\left.140^{\circ} \mathrm{C}-12 \mathrm{~min}(\mathrm{c})\right)$ and, finally, a dry stage conducted at $70^{\circ} \mathrm{C}$ until water activity $\left(\mathrm{a}_{\mathrm{w}}\right)$ reached around 0.300 .

\section{Drying Kinetics}

The kinetics of the banana drying process was studied by analysis of water loss, which is responsible for the change in mass. The Lewis model, an empirical drying model, shown in the following equation, was used.

$$
X^{*}=\frac{X-X_{e}}{X_{0}-X_{e}}=\exp (-k t)
$$

where $\mathrm{X}^{*}$ is the dimensionless moisture content, $\mathrm{X}_{0}$ is the initial moisture content, $\mathrm{X}_{\mathrm{e}}$ is the equilibrium 
moisture content, $\mathrm{k}$ is the empirical parameter in the drying model (Lewis model) and $t$ is the drying time.

The values of the required parameter $\mathrm{k}$ could be determined by fitting the Lewis model to the experimental data. This parameter was analyzed for either the complete process (HTST drying stage and a drying process at $70^{\circ} \mathrm{C}$ ), where parameter $\mathrm{k}$ was determined as $\mathrm{k}_{\text {total }}$, or the HTST drying stage only, where parameter $\mathrm{k}$ was determined as $\mathrm{k}_{\text {HTST. }}$ The nonlinear regressions were done using the Statistical program and the residual coefficient of the regression $\left(R^{2}\right)$ was calculated for each run.

\section{Water Activity $\left(\mathbf{a}_{\mathrm{w}}\right)$}

Water activity was determined for the dried banana using dew point equipment (Decagon CX2T) at $25^{\circ} \mathrm{C}$.

\section{Sensory Analysis}

The acceptability of crispness characteristic of seven different samples of dried banana was evaluated using sensory affective tests (Meilgaard et al., 1987). Thirty untrained panelists scored crispness using a 9-cm horizontal line scale. The line scale was anchored 1 centimeter from each end with "dislike extremely" and "like extremely" descriptors with marks at those reference points (hedonic scale). Evaluations were converted into a value from 0 to 10. Evaluations were conducted in separate booths in a controlled room under a red light to control for any effect of appearance of the samples. Water and crackers were provided to clean the palate before sampling. All the samples were placed on black plates randomly coded with three-digit numbers. Each run was evaluated on a different day. A twoway (product and assessor) variance analysis (ANOVA) was performed to determine whether significant differences existed between the runs. Tukey's test was conducted to determine the minimum significant differences (MSD). The SAS V.12.1 statistical program was used to evaluate the data.

\section{Instrumental Tests}

All compression tests were performed with a TAXT2i texture analyzer at a crosshead speed of $1 \mathrm{~mm}$ $\mathrm{s}^{-1}$. The texture analyzer was fitted with a HDP/VB Volodkevich Bite Jaws probe connected to a $5 \mathrm{~kg}$ load cell, and it was programmed to compress the samples to $50 \%$ of their original height. For each run intact dried banana was compressed and forcedeformation curve was obtained using Microsoft Excel (V. 4.0) software. Fracture behavior was characterized by maximum force $(\mathrm{N})$ and deformation at maximum force.

\section{RESULTS AND DISCUSSION}

\section{Water Activity $\left(\mathbf{a}_{\mathrm{w}}\right)$}

Table 1 shows mean values of water activity for dried banana. It is apparent that the values did not reach 0.300 as expected. However, it can be verified that higher HTST temperature and time resulted in lower water activity values (a range of 0.345 to 0.363 , of runs 4 to 7 ). These conditions resulted in a crispier product, which would be confirmed by the other measures (instrumental and sensory analyses).

\section{Sensory Analysis}

According to the ANOVA, there was a significant difference in acceptability of crispness characteristic. Therefore, Tukey's test was conducted to establish the MSD and to verify which runs were different from each other. The results obtained in the affective sensory tests are shown in Table 2.

Table 1: Mean values of water activity.

\begin{tabular}{|l|c|c|}
\hline Runs & $\mathbf{a}_{\mathbf{w}}$ & Standard error \\
\hline $1\left(130^{\circ} \mathrm{C}-9 \min \right)$ & 0.409 & 0.007 \\
$2\left(150^{\circ} \mathrm{C}-9 \mathrm{~min}\right)$ & 0.394 & 0.007 \\
$3\left(130^{\circ} \mathrm{C}-15 \mathrm{~min}\right)$ & 0.383 & 0.008 \\
$4\left(150^{\circ} \mathrm{C}-15 \mathrm{~min}\right)$ & 0.363 & 0.001 \\
$5\left(140^{\circ} \mathrm{C}-12 \min (\mathrm{a})\right)$ & 0.345 & 0.010 \\
$6\left(140^{\circ} \mathrm{C}-12 \min (\mathrm{b})\right)$ & 0.345 & 0.012 \\
$7\left(140^{\circ} \mathrm{C}-12 \min (\mathrm{c})\right)$ & 0.348 & 0.011 \\
\hline
\end{tabular}


Table 2: Acceptability tests for crispness of dried banana.

\begin{tabular}{|l|c|}
\hline Runs & Acceptance Mean* \\
\hline $4\left(150^{\circ} \mathrm{C}-15 \min \right)$ & $7.8^{\mathrm{a}}$ \\
$5\left(140^{\circ} \mathrm{C}-12 \min (\mathrm{a})\right)$ & $7.0^{\mathrm{a}, \mathrm{b}}$ \\
$6\left(140^{\circ} \mathrm{C}-12 \min (\mathrm{b})\right)$ & $6.8^{\mathrm{a}, \mathrm{b}}$ \\
$7\left(140^{\circ} \mathrm{C}-12 \min (\mathrm{c})\right)$ & $6.6^{\mathrm{a}, \mathrm{b}}$ \\
$3\left(130^{\circ} \mathrm{C}-15 \min \right)$ & $5.7^{\mathrm{b}, \mathrm{c}}$ \\
$2\left(150^{\circ} \mathrm{C}-9 \min \right)$ & $4.7^{\mathrm{c}, \mathrm{d}}$ \\
$1\left(130^{\circ} \mathrm{C}-9 \mathrm{~min}\right)$ & $4.3^{\mathrm{c}, \mathrm{d}}$ \\
MSD & 1.6 \\
\hline
\end{tabular}

*Means with the same letter do not differ significantly by Tukey's test $(\mathrm{p} \leq 0.05)$.

Run 4 had the highest acceptance mean, but Tukey's test showed no significant difference amongst this sample and samples in runs 5, 6 and 7 . Although in run 3 had a score higher than 5.0, there was no statistical difference amongst runs which were not accepted by the sensory panel (runs 1 and 2 with scores less than 5.0). The results of affective sensory tests showed that runs 4, 5, 6 and 7 had a enough dry level similar with the degree of crispness characteristic of a commercial dried and crispy fruit, since they were well accepted by the sensory panel.

\section{Instrumental Tests}

Since the force-deformation curves for dried banana were very heterogeneous under the same drying condition (samples in the same run had different curves), the curve that extended the maximum force value to near the mean maximum force for each dry condition was chosen. Runs with the same HTST temperatures were shown together in order to compare them (Figures 1, 2 and 3 ).

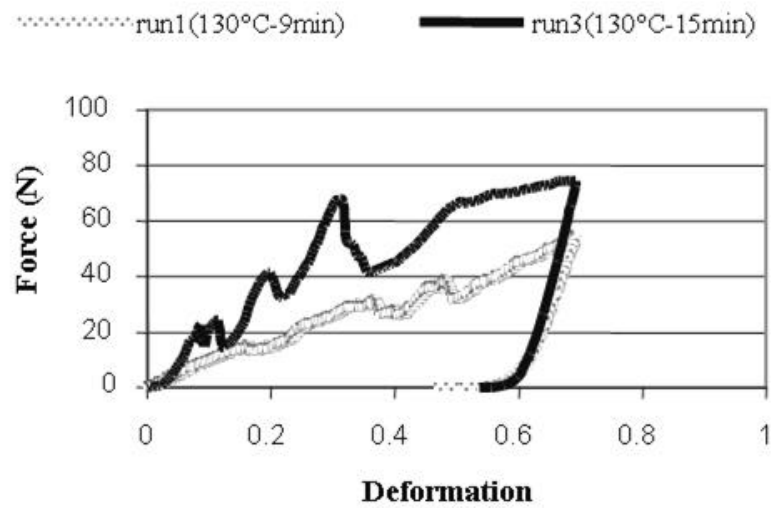

Figure 1: Typical force-deformation curve for dried banana at $130^{\circ} \mathrm{C}$.

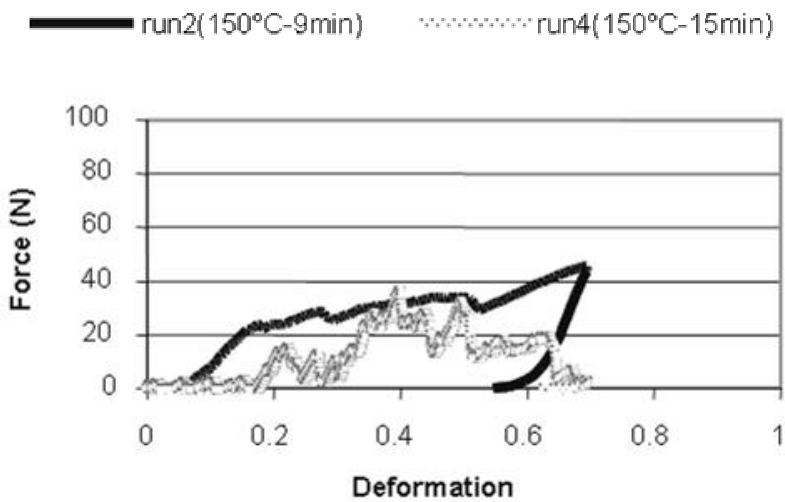

Figure 2: Typical force-deformation curve for dried banana at $150^{\circ} \mathrm{C}$. 

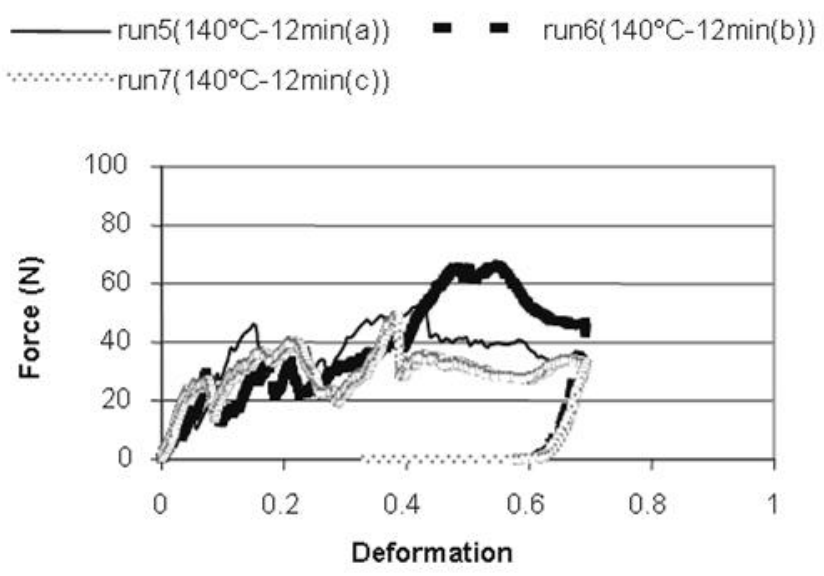

Figure 3: Typical force-deformation curve for dried banana at $140^{\circ} \mathrm{C}$.

Typical force-deformation curves showed many fracture points between the initial compression and deformation at maximum force. This indicates a crispy characteristic, since crispness is associated with rapid propagation of fracture, which in turn, necessitates brittle material. But important differences in the shape and amplitude can be observed for the same condition of HTST temperature. Figure 1 shows that an increase in the HTST time causes a large number of fracture points between the initial compression and the deformation at maximum force. So, as the fracture points increased, the crispness increased.

According to the literature, the increase in hardness as water activity increases can be explained by the fact that water acts as a plasticizer. This is due to the fact that a plasticized structure does not disintegrate easily, allowing the sample to remain intact and offering more resistance to deformation. In this study the opposite occurred for samples in runs 1 and 3 (Figure 1): although run 3 had a lower water activity value $\left(\mathrm{a}_{\mathrm{w}}=0.383\right)$ and more fracture points than run $1\left(a_{w}=0.409\right)$, the former required more force to break the sample, indicating that it was harder.

Figure 2 shows that the run 2 samples required more force to break than those in run 4. This indicated that as the breaking force (hardness) increased, crispness decreased. Moreover, run 4 samples had many fracture points between the initial compression and deformation at maximum force, indicating a crispy characteristic, and their water activity value was in accordance with values in the literature. Analysing the curves with the same HTST time and different temperatures, runs 1 and 2 in Figures 1 and 2 , it can be perceived that as temperature increased, the fracture points increased and the force necessary to break the sample decreased. They also show that a decrease in water activity value occurs with an increase in HTST temperature $\left(a_{w}=0.409\right.$ for run 1 and $a_{w}=0.394$ for run 2). Similar behaviour occurred for curves with 15 min HTST and different temperatures (runs 3 and 4 in Figures 1 and 2). But in this case the increase in the HTST temperature produced a significant increase in the fracture points between the initial compression and deformation at maximum force. Moreover, run $4\left(150^{\circ} \mathrm{C}\right)$ required less force to break samples and had a lower water activity value $\left(\mathrm{a}_{\mathrm{w}}=\right.$ $0.363)$ than run 3 at $130^{\circ} \mathrm{C}\left(\mathrm{a}_{\mathrm{w}}=0.383\right)$, indicating a higher crispness value. Figure 3 shows three equal HTST temperature and time conditions. It can be observed that these curves had similar amplitude force and fracture points and water activity values were lower than those in the other runs, which resulted in crispy products.

\section{Drying Kinetics}

First parameter $\mathrm{k}$ (Lewis model) was fitted to the complete drying process $\left(\mathrm{k}_{\mathrm{total}}\right)$, as shown in Table 3.

According to the literature, despite the empirical character of kinetics parameters, some physical meaning may be attributed to them, taking into account the kind of mathematical function fitted. In this work, parameter $\mathrm{k}$ is associated with diffusivity and shape and it can be related to the structure of the material, including its water content. So it is important to say that to fit all of the drying experimental data this parameter involved three different drying stages: a predehydration in the air drier for five minutes at $70^{\circ} \mathrm{C}$, a high temperature 
and short time drying stage and a drying process at $70^{\circ} \mathrm{C}$.

For higher $\mathrm{k}$ values the mass transfer will be more efficient. This is clearly shown in Table 3, where for the same HTST temperature and different times (runs 1 and 3; runs 2 and 4), parameter k increased as the HTST time increased. This indicates that higher periods at high temperatures will facilitate water loss. Runs 5, 6 and 7 showed $\mathrm{k}$ values that ranged between values for the other runs, as expected. On the other hand, run 7 showed a $\mathrm{k}$ value different from those for runs 5 and 6 . Considering that these runs were under the same drying conditions $\left(140^{\circ} \mathrm{C}\right.$ $12 \mathrm{~min}$ ), there may have been a difference in chemical composition, probably due to the fact that those bananas (runs 5 and 6) were purchased at a different market (as explained in the section "Material Preparation"), but this is hypothetical, since it was not evaluated in this work.

It is apparent that the higher the HTST temperature, the higher the $\mathrm{k}$ value and the quicker the water loss, which implies a fast decrease in moisture content of the product. However, changes in the solid matrix at the end of the HTST stage may have occurred. In order to study the effect of the HTST stage on the k kinetics parameter, the drying kinetics was combined with this stage only and the results are shown in Table 4.

Table 3: Parameter $k$ (Lewis model) considering the complete process $\left(k_{\text {total }}\right)$.

\begin{tabular}{|l|c|c|c|c|}
\hline Runs & $\mathbf{X}_{\mathbf{0}}$ & $\mathbf{k}_{\text {total }}$ & $\begin{array}{c}\mathbf{R}^{\mathbf{2}} \\
\left(\mathbf{k}_{\text {total }}\right)\end{array}$ & $\begin{array}{c}\text { Standard error } \\
\left(\mathbf{k}_{\text {total }}\right)\end{array}$ \\
\hline $1\left(130^{\circ} \mathrm{C}-9 \mathrm{~min}\right)$ & 3.00 & 3.295 & 0.99 & 0.07 \\
$3\left(130^{\circ} \mathrm{C}-15 \mathrm{~min}\right)$ & 2.58 & 3.660 & 0.99 & 0.05 \\
$5\left(140^{\circ} \mathrm{C}-12 \mathrm{~min}(\mathrm{a})\right)$ & 2.44 & 3.789 & 0.97 & 0.14 \\
$6\left(140^{\circ} \mathrm{C}-12 \mathrm{~min}(\mathrm{~b})\right)$ & 2.44 & 3.744 & 0.97 & 0.14 \\
$7\left(140^{\circ} \mathrm{C}-12 \mathrm{~min}(\mathrm{c})\right)$ & 2.79 & 4.122 & 0.99 & 0.07 \\
$2\left(150^{\circ} \mathrm{C}-9 \mathrm{~min}\right)$ & 3.00 & 3.845 & 0.98 & 0.09 \\
$4\left(150^{\circ} \mathrm{C}-15 \mathrm{~min}\right)$ & 2.79 & 4.566 & 0.99 & 0.07 \\
\hline
\end{tabular}

Table 4: Parameter $k$ (Lewis model) considering the HTST stage $\left(k_{\mathrm{HTST}}\right)$

\begin{tabular}{|l|c|c|c|c|}
\hline Runs & $\mathbf{X}_{\mathbf{0}}$ & $\mathbf{k}_{\mathbf{H T S T}}$ & $\mathbf{R}^{\mathbf{2}}\left(\mathbf{k}_{\mathbf{H T S T}}\right)$ & $\begin{array}{c}\text { Standard error } \\
\left(\mathbf{k}_{\text {HTST }}\right)\end{array}$ \\
\hline $1\left(130^{\circ} \mathrm{C}-9 \mathrm{~min}\right)$ & 3.00 & 3.641 & 0.99 & 0.01 \\
$3\left(130^{\circ} \mathrm{C}-15 \mathrm{~min}\right)$ & 2.58 & 3.789 & 0.99 & 0.01 \\
$5\left(140^{\circ} \mathrm{C}-12 \mathrm{~min}(\mathrm{a})\right)$ & 2.44 & 4.073 & 0.98 & 0.02 \\
$6\left(140^{\circ} \mathrm{C}-12 \mathrm{~min}(\mathrm{~b})\right)$ & 2.44 & 4.022 & 0.98 & 0.02 \\
$7\left(140^{\circ} \mathrm{C}-12 \mathrm{~min}(\mathrm{c})\right)$ & 2.79 & 4.289 & 0.98 & 0.02 \\
$2\left(150^{\circ} \mathrm{C}-9 \mathrm{~min}\right)$ & 3.00 & 4.165 & 0.98 & 0.02 \\
$4\left(150^{\circ} \mathrm{C}-15 \mathrm{~min}\right)$ & 2.79 & 4.651 & 0.98 & 0.04 \\
\hline
\end{tabular}

For the same moisture content of the sample, the solid matrix should have the same tendency to shrink when removed from the HTST stage. So, analysing Table 4 it can be verified that the HTST stage depends on initial moisture content. Runs 1 and 2 had the same initial moisture content but run 2 had a higher $\mathrm{k}$ value than run 1 . This indicates that the higher the HTST temperature, the higher the $\mathrm{k}$ value, facilitating mass transfer. Similar behaviour occurred in runs 3 and 4. On the other hand, run 1 showed the lowest $\mathrm{k}$ value in the HTST stage. Probably a fragile solid matrix was formed at the end of the HTST stage due to the fact that its initial moisture content was the highest. Runs 5 and 6 showed the same initial moisture content and a very similar $\mathrm{k}$ value. Run 7 showed an initial moisture content near those in runs 5 and 6, but a higher $\mathrm{k}$ value. Again, there may have been a difference in chemical composition, but this was not evaluated in this work.

Considering that the initial moisture contents in runs 2 and 7 were different, the solid matrix rigidness should have been different, and a higher $\mathrm{k}$ value for run 2 was expected. But this did not occur. Thus, the $\mathrm{k}$ values provide evidence that the $140^{\circ} \mathrm{C}$ (run 7) produced a higher porosity at the end of the HTST stage than the $150^{\circ} \mathrm{C}$ (run 2). Taking this into account, HTST time had a more significant effect on porosity than HTST temperature. Comparing runs with the same HTST temperature but different times (runs 1 and 3; runs 2 and 4), it can be observed that the higher the HTST time (15 minutes), the higher the $\mathrm{k}$ values, which is consistent with the physical 
eaning attributed to $\mathrm{k}$ parameter values.

\section{CONCLUSIONS}

Crispy banana was obtained for runs $4\left(150^{\circ} \mathrm{C}\right.$ $15 \mathrm{~min}), 5\left(140^{\circ} \mathrm{C}-12 \mathrm{~min}(\mathrm{a})\right), 6\left(140^{\circ} \mathrm{C}-12 \mathrm{~min}(\mathrm{~b})\right)$ and $7\left(140^{\circ} \mathrm{C}-12 \mathrm{~min}(\mathrm{c})\right)$ with water activity values ranging between 0.345 and 0.363 . Results showed that HTST temperature and time affect the texture (sensorialy and instrumentally) of dried banana. The product was perceived to be crispier and required less force to break as HTST temperature and time increased, and it also showed many fracture points. It was not possible to find a correlation between parameter $\mathrm{k}$ and the HTST stage. This was due to the fact that the samples' initial moisture content showed a more significant effect on this parameter than HTST temperature and time. The results showed that there is a relationship between sensory crispness, instrumental texture parameters and the HTST stage.

\section{ACKNOWLEDGMENTS}

The authors would like to express their thanks to $\mathrm{CNPq}$ (Conselho Nacional de Desenvolvimento Científico e Tecnológico) for its financial support through a doctoral scholarship for the first author, CAPES (Coordenação de Aperfeiçoamento de Nível Superior) for providing the Master's scholarship and the Department of Food Engineering at the State University of Campinas (Unicamp).

\section{NOMENCLATURE}

$\begin{array}{ll}\mathrm{a}_{\mathrm{W}} & \begin{array}{l}\text { water activity } \\ \text { empirical parameter in } \\ \text { the drying model }\end{array} \\ \mathrm{R}^{2} & \begin{array}{l}\text { regression coefficient } \\ \text { drying time }\end{array} \\ \mathrm{t} & \begin{array}{l}\text { dimensionless moisture } \\ \mathrm{X}^{*}\end{array} \\ \mathrm{X} & \begin{array}{l}\text { content } \\ \text { moisture content }\end{array}\end{array}$

(gmoisture gdry matter ${ }^{-1}$ )

\section{Symbols}

ANOVA analysis of variance

HTST high temperature ands short time

MSD minimum significant

\section{Subscripts}

$\begin{array}{llr}\text { w } & \begin{array}{l}\text { water } \\ \text { at equilibrium moisture }\end{array} & (-) \\ \text { content } & \left(\mathrm{X}_{\mathrm{e}}\right) \\ \text { at initial moisture } & \left(\mathrm{X}_{0}\right) \\ \text { total } & \begin{array}{l}\text { content } \\ \text { referring to the } \\ \text { complete drying } \\ \text { referring to the HTST } \\ \text { stage }\end{array} & \begin{array}{r}\text { (kinetic } \\ \text { parameter k) } \\ \text { (kinetic }\end{array} \\ \text { HTST } & \text { parameter k) }\end{array}$

\section{REFERENCES}

De Belie, N., De Smedt, V. and De Baerdemaeker, J., Principal Component Analysis of Chewing Sounds to Detect Differences in Apple Crispness, Postharvest Biology and Technology, Vol. 18, p. 109-119 (2000).

Duizer, L.M. and Campanella, O.H., Sensory, Instrumental and Acoustic Characteristics of Extruded Snack Food Products, Journal of Texture Studies, Vol. 29, no. 4, p. 397- 411 (1998).

Katz, E.E. and Labuza, T.P., Effect of Water Activity on the Sensory Crispness and Mechanical Deformation of Snack Food Products, Journal of Food Science, Vol. 46, p. 403-409 (1981).

Luyten, H., Plijter, J.J. and Vliet, T.J., Understanding the Sensory Attributes Crispy and Crunchy: an Integrated Approach, Proceedings of the $3^{\text {rd }}$ International Symposium on Food Rheology and Structure, Zurich, Switzerland, p. 379-384 (2003).

Meilgaard, M., Civille, G.V. and Carr, B.T., Sensory Evaluation Techniques, CRC Press, Florida, USA, p.281 (1987).

Peleg, M., The Mechanical Properties of Brittle, Cellular and Particulated Foods, Proceedings of the $3^{\text {rd }}$ International Symposium on Food Rheology and Structure, Zurich, Switzerland, p. 75-81 (2003).

Roudaut, G., Dacremont, C. and Le Meste, M., Influence of Water on the Crispness of CerealBased Foods: Acoustic, Mechanical and Sensory Studies, Journal of Texture Studies, Vol. 29, no. 2, p. 199-213 (1998).

Roudaut, G., Dacremont, C., Le Meste, M., Pamies, B.V. and Mitchell, J.R., Understanding the Texture of Low Moisture Cereal Products: Mechanical and Sensory Measurements of Crispness, Journal of Science and Food Agriculture, Vol. 80, p. 1679-1685 (2000). 
Saklar, S., Ungan, S. and Katnas, S., Instrumental Crispness and Crunchiness of Roasted Hazelnuts and Correlations with Sensory Assessment, Journal of Food Science, Vol. 64, no. 6, p. 10151019 (1999).

Szczesniak, A.S., Texture is a Sensory Property, Food Quality and Preference, Vol. 13, p. 215-225 (2002).
Toledo, R.T., Dehydration, In: Toledo, R.T., Fundamentals of Food Process Engineering, $2^{\text {nd }}$ ed., Chapman \& Hall, New York (NY), USA, p. 456-506 (1991).

Vincent, J.F.V., The Quantification of Crispness, Journal of Science and Food Agriculture, Vol. 78, p. 162-168 (1998). 